\title{
Service Delivery in Substance Abuse Treatment: Reexamining "Comprehensive" Care
}

\section{POLICY PERSPECTIVE}

RESEARCH SUGGESTS

THAT WRAPAROUND

SERVICES ARE BENEFICIAL

TO IMPROVING TREATMENT

OUTCOMES FOR INDIVIDUALS

WITH SUBSTANCE USE

DISORDERS. YET, IT CAN BE

DIFFICULT FOR TREATMENT

AGENCIES TO PROVIDE

SUCH SERVICES UNLESS

THEY HAVE ADEQUATE

ACCESS TO NECESSARY

RESOURCES. POLICY-

MAKERS CAN PLAY A ROLE

IN IMPROVING SUBSTANCE

ABUSE TREATMENT BY

OFFERING FUNDING

FOR COMPREHENSIVE

WRAPAROUND SERVICES.

THEY CAN ALSO HELP

IMPROVE CARE BY

SUPPORTING LINKAGES

AMONG AGENCIES THAT

OFFER DIFFERENT BUT

COMPLEMENTARY SERVICES

TO INDIVIDUALS WITH

SUBSTANCE USE DISORDERS.

\section{Background}

$\uparrow$ he National Institute on Drug Abuse endorses the use of core and wraparound services as part of addiction treatment ${ }^{1}$. Core services include those related to diagnosis and treatment such as intake services, treatment plans, behavioral therapy, substance use monitoring, case management, pharmacotherapy, support groups and continued care. Wraparound services, including transportation and childcare assistance or links to legal, financial, employment, or medical resources, facilitate access to treatment, improve retention and address co-occurring problems. While core services are offered to some degree by nearly all addiction programs, there is more variation in wraparound services that programs offer. Research suggests, however, that providing wraparound services for those in substance abuse treatment results in improved outcomes and greater retention.

In their study, "Service Delivery in Substance Abuse Treatment: Reexamining 'Comprehensive' Care," Lori J. Ducharme, Ph.D. and colleagues examine organizational characteristics and the availability of services in 754 treatment programs. Of these programs, 100 were government-operated, 254 were publicly-funded nonprofit, 277 were privately-funded nonprofit and 118 were private for-profit.

\section{Key Findings}

- When comparing government-operated, publicly-funded nonprofits, privatelyfunded nonprofits and private for-profit organizations, differences exist in structural, staffing and client characteristics of programs offered. Privatelyfunded nonprofits were more likely than other agency types to be hospitalbased, accredited by the Joint Commission on Accreditation of Healthcare Organizations, employ counselors with master's-level degrees, and serve opiatedependent clients. Publicly-funded nonprofits were more likely than both types of private sector organizations to receive referrals from social service organizations and the legal system.

- Statistical differences exist in the types of services that are offered by funding source of treatment agencies. With respect to core services, governmentoperated and publicly-funded nonprofits were more likely than private agencies to use the Addiction Severity Index, an instrument that assesses problems related to substance use including medical status, employment and support, drug use, alcohol use, legal status, family/social status, and psychiatric status. Privately-funded nonprofits were more likely to offer 12-step groups than both publicly-funded nonprofits and privately-funded for-profit agencies. Publiclyfunded nonprofits were significantly less likely than the other agencies to use

1 NIDA. Principles of Drug Addiction Treatment: A Research Based Guide. NIH Publication No. 00-4180. Rockville, MD: NIDA; 2000.

2 Ducharme LJ, Mello HL, Roman PM, et al. "Service Delivery in Substance Abuse Treatment: Reexamining 'Comprehensive’ Care.” Journal of Behavioral Health Services \& Research, 34(2): 121-136, April 2007. http://wrwe.fmbi.usf.edu/jbhsr/toc/34.html\#2 
pharmacotherapies. With respect to wraparound services, publicly-funded treatment centers (including both government-operated and publicly-funded nonprofits) were more likely than privately-funded agencies to offer child care, transportation services and a dedicated treatment track for individuals with HIV/ AIDS. In addition, publicly-funded nonprofits were significantly more likely than privately-funded agencies to provide employment or vocational services. Publiclyfunded nonprofits were more likely than privately-funded nonprofits to offer integrated care, financial services and legal services.

- Organizational characteristics of agencies are related to comprehensiveness of care (i.e., the number of core and wraparound services offered). Overall, publicly-funded agencies offered more services than privately-funded ones as did agencies with more employees and agencies that treated more female clients. Government agencies (as compared to privately-funded nonprofits) offered more core services, as did programs that were hospital-based, had more employees and served more opiate-dependent clients. Both types of publicly-funded agencies offered more wraparound services than private agencies, as did agencies with a higher percentage of female clients.

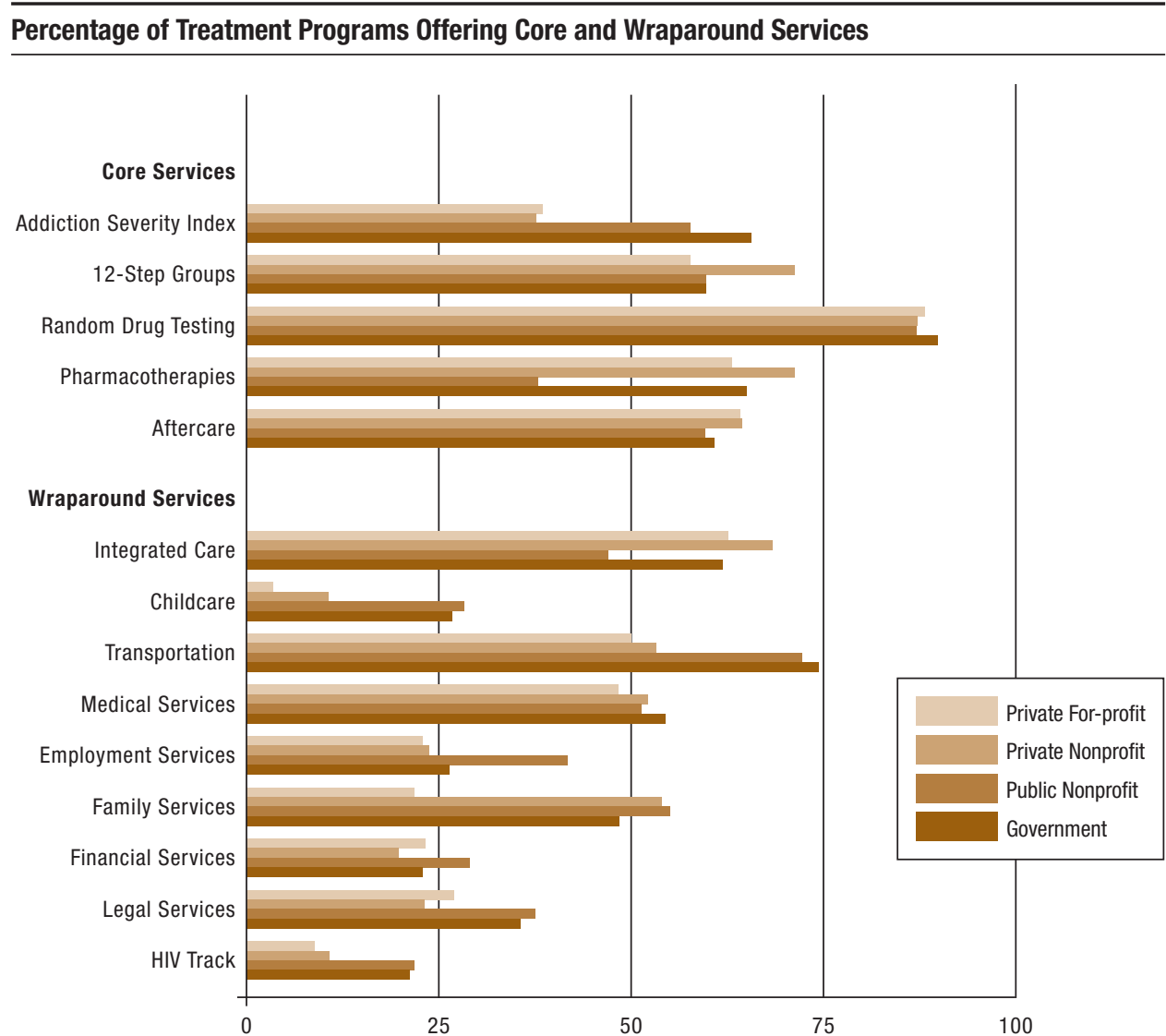

-Deanna Lewis Deanna Leweis is a Rutgers University/Robert Wood Johnson Foundation Policy Analyst. 